\title{
Micro-International Units per Milliliter per Meter Squared
}

National Cancer Institute

\section{Source}

National Cancer Institute. Micro-International Units per Milliliter per Meter Squared. NCI

Thesaurus. Code C119526.

A unit of concentration (biologic activity) equal to one micro-international unit per

milliliter, divided by meters squared. 